\title{
A New Approach of Ideological and Political Education in Colleges and Universities with School History Museum as Carrier
}

\author{
Liu Peiqi \\ School of Marxism \\ Wuhan University of Science and Technology \\ Wuhan Hubei, 430065 \\ e-mail:460848517@qq.com
}

\begin{abstract}
The School history museum is a valuable asset accumulated in the course of school development. It is of great importance to develop and utilize the school history muse um to pass on the excellent historical culture of colleges and universities, improve the pertinence of ideological and political education work and create a good atmosphere of ideological and political education. This paper explored the new ways of ideological and political education with the school history muse um as the carrier, and put forward measures to strengthen the building of the staff of the university history museum, apply modern information technology and develop the new resources of the school history museum. It also fully explored the value of the school history museum to carry out ideological and political education, expanded the ideological and political education frontiers, and enhanced the attractiveness and appeal of ideological and political education, so as to achieve the goal of highly integrating school history culture and ideological and political education.
\end{abstract}

Keywords—school history museum; cultural university history; ideological and political education; approaches

In December 2016, General Secretary Xi Jinping pointed out at the National Conference on Ideological and Political Work in Colleges and Universities: "Tdeological and political education fundamentally teaches students how to behave. It must center on students, care for students, serve students, and constantly improve students' ideological level, political consciousness, morality, cultural literacy to make students become talents with both political integrity and professional competence.” Later in February 2017, CPC Central Committee and the State Council declared in the Opinions on Strengthening and Improving Ideological and Political Work in Colleges and Universities that strengthen and improve ideological and political work in colleges and universities involve what kind of university is going to be built, and how to run a university. It is a major political task and strategic project related to the party's leadership over the university and the succession of the socialist cause with Chinese characteristics. This fully demonstrates the necessity of ideological and political education in colleges and universities and the Party Central Committee attaches great importance to ideological and political education.
With the development of education and information technology, the ideological and political education in colleges and universities is not only in the form of classroom teaching, but also in all aspects of campus culture. The school history museum is part of the campus cultures. With its own profundity and unique historical features, it has become a new frontier for ideological and political education, with great theoretical and practical significance. Therefore, it is an important subject of ideological and political education research in colleges and universities to set the school history museum as the carrier, promote the integration of school history culture and ideological and political education, expand the ideological and political education frontiers, and enhance the attractiveness and appeal of ideological and political education.

\section{Strengthen the Building of the Personnel Team} OF THE UNIVERSITY HISTORY MUSEUM

\section{A. Give full play to the leading and supporting role of university leaders}

As an important part of the ideological and cultural culture of colleges and universities, university leaders should attach importance to and utilize the school history museum as a carrier to carry out the ideological and political education [1], establish a long-term transparent management mechanism, and effectively incorporate the development of the school history museum into the ideological and political education system. Innovate the school history museum construction mode, make full use of the school history museum to carry out ideological and political education activities, and combine the cultivation of college students' humanities quality, and strive to create a new phase of ideological and political education. What's more, they should provide the necessary human, material and financial resources for the construction of the history museum, and actively explore the new ideas and new dimensions of construction, so that the development of the university history museum can better meet the new requirements of ideological and political education. Therefore, the attention and support of university leaders help the school history museum to better play its ideological and political education function, which is conducive to creating a strong educational atmosphere on 
campus and strengthening the function of environmental education.

\section{B. Establish and improve the staff management system of the museum}

Management is indispensable for ensuring the effective operation of an organization. An effective management can enhance the operational efficiency of the organization and give full play to the potential of the organization. In order to build a high-efficiency, high-quality staff team of the school history museum, it is necessary to establish and improve the talent selection, appointment and supervision mechanism, strengthen and standardize the management of the staff of the school history museum, to ensure the smooth running of the school history museum. At the same time, the school history museum should formulate an operational system related to ideological and political education, improve the work organization and manning, clarify development plan and conduct effective personnel management, refine work responsibilities, optimize reward and punishment systems, to provide guarantee for launching ideological and political education and lay a good foundation for the future development of the school history museum.

\section{Organize and train college students to interpret}

The school history museum is the best platform for students to understand the school. It is an important place for freshmen's education, party members' education and training, teacherstudent moral education, and humanities education. Visiting the school history museum is an important way for students to get to the essence of school history, to understand the history and culture of colleges and universities, to know schools, and love schools. In addition to the lecturers in the school history museum, it is also necessary to train students to interpret and build the interpretation team, which not only solves the problem of insufficient staff of the school history museum, but also enhances the service consciousness of the university students and their sense of identity and pride of their school[2].

To build the student interpretation team, we must select courteous and graceful students with good looking who are willingness to do volunteer service. They'd better have strong language expression, communication and adaptability, and enhance their attractiveness and appeal with eloquent explanations to achieve a good interpretation. In addition, the student lecturers should be professionally trained in the history and culture of the school. Student lecturers infect others with emotional language, rendering the atmosphere of loving school, inspiring and uniting people, and making visitors consciously combine their personal ideals with schools and society, laying the foundation for students' subsequent study and life, thus achieving the purpose of ideological and political education with the school history museum as the carrier.

\section{COMPREHENSIVE APPLICATION OF MODERN INFORMATION} TECHNOLOGY

\section{A. Building Exquisite Online History Museum}

At the conference on ideological and political work in colleges and universities in China, General Secretary Xi Jinping pointed out, "teachers should guide students to keep an eye on the current affairs in the world, advance with the times and use novel ways in the class while doing ideological and political work". With the rise of information technology, the internet is strongly promoting the constant development of human society and profoundly changing people's production and life style. As a new carrier of ideological and political education, History Museum should make the most of the internet to build an exquisite online museum. Without the limitation of time and space, online museum is a kind of supplement and sublimation of the History Museum, showing its elegance to the utmost extent. Using mobile phones, computers and other electronic equipment, students can browse the website to learn school history anytime and anywhere. It makes them deeply understand the profundity and glory of the history, experience the dense cultural atmosphere and improve ideological and moral cultivation. Thus, they will be confident of the school's prospect and strive for it. In addition, online museum should set up some interactive sections like comments, games and diorama, providing a platform for students to exchange. So, it can help them deeply understand and be culturalized by school history.

\section{B. Setting up QR Code for Consultation}

Scanning QR code to know the information has already become a modern life style. With the limits of human resources, commentators fail to serve all visitors. Therefore, the QR code can fill the gap. The code uses high-density coding patterns and enjoys a wide range from picture, video to character and other digital information. Various languages and characters can be showed to satisfy visitors from all over the world. The code can accommodate more than 500 Chinese characters, through which the visiting and learning becomes more convenient. Information can be showed with a simple scan, which meets students' demand. What's more, with the low cost and long life span, the cost-effective QR code accords with the request that ideological and political education must be conducted for a long time. Thus, we transform the explaining content into QR code and set up in different sections in the museum, providing convenience for students to learn the school history and further enhancing their consciousness and feelings of loving their own school and China.

\section{Launching Modern Technology to Increase Interaction}

At the conference on ideological and political work in colleges and universities in China, General Secretary Xi Jinping indicated, "we should use the new media and technology to make our job full of vitality and promote the highly combination of traditional advantages of ideological and political work with information technology, increasing the sense of times and attraction”. As the new carrier of ideological and political education, the History Museum should keep pace with the times and use modern methods to combine school 
history and culture with modern information technology, creating an instructive environment with dense cultural atmosphere. For example, the History Museum in Lingnan Normal University has a 52-inch and an 80-inch All-in-one PC touch[3], allowing visitors to choose in accordance with preferences. With the integration of sound, light and electricity, pictures and words as an assistant, multimedia would show the content, making visitors feel as if he or she is there. Meanwhile, inquiry and advertisement machines are set up for visitors to look up outstanding alumni and school history[3].The comprehensive application of modern technology make students learn the history, culture and educational theory in an all-round and multiform way, and increase their sense of belonging and pride. It will promote the museum to play a greater role in ideological and political education. Therefore, launching various modern equipment in History Museum not only integrates modern technology with information technology, but also enhances its attraction and appealing of ideological and political education.

\section{Actively Developing New Resources of History MUSEUM}

\section{A. Exploiting School History, involving more participators}

History Museum is a collection and exhibition of historical material in different period. We use these data to bring history back to life and make scene reconstruction. Through enriching collection and increasing their meaning, we actually complete and enrich the school history, which is the best way to improve museum's quality and expand the influence of ideological and political education. We not only need to fully exploit the information from archives and find new material, making them show the long history and profound culture, but also involve more participators into collecting school history[4].Its influence can be expanded by the participation of school, teachers, students and alumni. While collecting the data, they can be influenced by what they see and hear. So they would feel the charming of school and carry forward the excellent traditional culture, which can inherit culture and meet the demands of ideological and political education in colleges and universities.

\section{B. Gathering Alumni Resource, enriching collection}

There are many outstanding alumni in all over the world, doing different jobs. Their experience, entrepreneurial ideas and thinking patterns are huge spiritual treasure for ideological and political education. Through showing the typical examples of successful alumni, we can integrate their experience into ideological and political education, making them great model of students, encouraging and uniting them. So they can be enlightened to enhance their social responsibility and consciousness of historical mission, so as to realize the goal of ideal and faith education. Taking outstanding alumni as example is beneficial for students to establish correct outlook on world, life and value and enhance their quality of ideology and morality. It also popularizes ideological and political thoughts, which can lay a solid foundation for students to create huge wealth for the society. Besides, History Museum should constantly update and complete alumni resource. We proactively organize students to carry out social activities in vacations and looking for the experience of successful alumni on the spot. It will expand their horizons and further stimulate them to study hard and succeed[5].At the meantime, we should invite excellent alumni to school at regular intervals in forms of lecture and face to face to interact with students. In this way, we can inherit their deeds and entrepreneurial ideas, which play a significant role in gathering alumni resources, enriching collection and campus culture.

\section{Opening Special exhibition, highlighting era characteristics}

With the limited space of History Museum, basic display fails to go into details of themes. Many worthy pictures and relics cannot be exhibited. However, special exhibition chooses one aspect to specify and enrich the neglected things. Take an example of the History Museum of Nanjing University, it once held the commemorative exhibition of Professor Chen Jia's centennial birthday, exhibition of the heroes of "atomic and hydrogen bombs and artificial satellite" from Nanjing University, commemorative exhibition of Kuang Yaming's centennial birthday, Anti-Janpanese War in the memory of Nanjing University and other special exhibitions[6].These exhibitions all display in a short time with flexible themes and strong timeliness and keep pace with the epoch, satisfying students' increasing cultural demands. Besides, they also play unique role in serving the society, enhancing students' ideological and political quality and promoting the spirit of the times and advanced culture. Universities and colleges can hold special exhibitions according to traditional festivals, school anniversary and memorial days of celebrities, increasing their willing to learn the history and spirit of school and further achieving ideological and political education.

\section{CONCLUSION}

We use History Museum as the carrier to conduct ideological and political education. It accords with the new direction, idea and request of the current times. The museum is given new value in new era, promoting the new function of school history and culture. It makes the museum show vitality and creativity and has important meaning to strengthen and improve the ideological and political education of the undergraduates, as well as enhance their overall quality. Administrators, with an earnest and responsible attitude, must stick to the "people-oriented" working concept; complete the management and construction of History Museum, exploiting the development and application of the museum, deeply digging the value of school history and culture, so as to integrate it with the ideological and political education.

\section{REFERENCE}

[1] Bian Zhao.Effective Methods to Innovate the Ideological and Political Education of the Graduates-Based on the Archives of Universities and Colleges[J].Reality Only, 2011, (11): 41-43.

[2] Chen Yuan.Discussion on the Education Function of History Museum in Universities and Colleges under the Training Mode of Innovative Personnel[J].Lantai World, 2014, (2): 124-125.

[3] Qiu Jin.Digging the Sustainable Development of School History from the Archives[J].Science and Technology \& Innovation, 2017, (1): 43-44. 
[4] Sun Jianyun.Strengthening the Construction of History Museum and Developing Moral Class[J].Archives \& Construction, 2009, (2): 22-23.

[5] An Ying, Zhang Yu, Wang Tao.In History Museum as the Carrier of the College Students' Ideological Education Effectiveness Research-in
Outstanding alumni Typical Demonstration Effect, for Example[J].Journal of Jiamusi Vocational Institute, 2015, (4): 103-104.

[6] The History Museum of Nanjing University. http://museum.nju.edu.cn/. 